\title{
IMPLEMENTASI MANAJEMEN PENDIDIKAN BERBASIS SYARIAH DI STAI AL-HIDAYAH BOGOR
}

Oleh: Muhammad Priyatna*

\begin{abstract}
Islam is the perfect religion that regulates all aspects of human life, including aspects of education. Education is one of the essential needs of man, because through education, people will be able to develop their potentials towards a better life. In the conception of Islam, the main function of educational institution is as a medium of education realization in order to realize servitude to Allah and to develop any talents or potential people in accordance with their respective trends. In the Islamic view, everything must be done neatly, correctly, orderly and organized. The process must be followed properly. Something should not be done carelessly. In this case, the STAI Al-Hidayah Bogor set the vision and mission as an institution of higher education which is based on the concept and practice of sharia in its management which includes kinds of activities, like planning, supervision, organization, evaluation, and so on. This articel is striving to explain the concept and its implementation of education management sharia-based in accordance with studies at STAI Al-Hidayah Bogor. Through this paper is expected to provide knowledge about the concept and model of education management approach to the implementation of sharia in Islamic educational institutions. This study is adescriptive qualitative research methods. The writer restricts the research objects in to the concept and implementation of Islamic-based education management in STAI Al-Hidayah, obtained through a reviewof the relevant reference works of writers before, and observations and interview sconcerning management officers of STAI Al-Hidayah Bogor. The sources of secondary data obtained from books, papers or article general managementand management education that Islamic approach. In-depth study has concluded important basic concepts, namely the concept of implementing Sharia-Based Management in STAI Al-Hidayah Bogor, implemented starting from the planning, organizing, directing, monitoring and evaluation, through the official rules in the regulation of the management of STAI Al-Hidayah has based and adapted to Islamic rule, although it is still much that needs to be refined in the details of its implementation. The writer invites, the Muslim community should give greater attention to the management of educationat every step of its implementation in order to remain committed in the corridor and Islamic guidance, as many practices exemplified by the Prophet Muhammad
\end{abstract}

Kata kunci: manajemen pendidikan, syar'ah, STAI Al-Hidayah Bogor

\section{A. Pendahuluan}

Pada saat ini manajemen sudah banyak dikenal di kalangan masyarakat secara luas. Setiap organisasi baik yang mencari keuntungan maupun lembaga sosial hampir semuanya menyadari pentingnya manajemen.

Tidak dapat disangkal lagi bahwa manajemen adalah suatu hal penting yang menyentuh, memengaruhi, dan bahkan merasuki hampir seluruh aspek kehidupan manusia layaknya darah dan raga. Juga telah dimengerti bahwa dengan manajemen, manusia mampu mengenali kemampuannya berikut kelebihannya dan kekurangannya. Begitu juga dalam dimensi pendidikan Islam, manajemen telah menjadi sebuah istilah yang tak dapat dihindari demi tercapainya suatu tujuan. Untuk mencapai tujuannya, pendidikan Islam harus memiliki manajemen yang baik dan terarah.

Adapun manajemen pendidikan Islam yang dimaknai sebagai suatu proses 
penataan atau pengelolaan lembaga pendidikan Islam yang melibatkan sumber daya manusia Muslim dan non-Muslim dalam menggerakkannya untuk mencapai tujuan pendidikan Islam secara efektif dan efisien, memiliki konsep dasar dalam Islam sebagai suatu sistem hidup yang sempurna. Akan tetapi kesalahan kebanyakan dari kaum muslimin dalam memahami konsep manajemen dari sudut pandang Islam adalah karena masih mencampuradukan antara ilmu manajemen yang bersifat teknis (uslub) dengan manajemen sebagai aktivitas. Kerancuan ini akan mengakibatkan kaum muslimin sulit membedakan mana yang boleh diambil dari ilmu manajemen saat ini dan mana yang tidak. Oleh karena itu melalui tulisan ini, penulis mencoba mendeskripsikan konsep manajemen pendidikan berbasis syariah beserta strategi dan contoh implementasi yang telah dilaksanakan di STAI AlHidayah Bogor.

\section{B. Pembahasan}

\section{Manajemen Syariah}

Menurut Didin dan Hendri dalam buku mereka Manajemen Syariah dalam Praktik, Manajemen bisa dikatakan telah memenuhi syariah bila: pertama, manajemen ini mementingkan perilaku yang terkait dengan nilai-nilai keimanan dan ketauhidan. Kedua, manajemen syariah pun mementingkan adanya struktur organisasi. Ini bisa dilihat pada surat AlAn'am ayat 65, "Allah meninggikan seseorang di atas orang lain beberapa derajat". Ini menjelaskan bahwa dalam mengatur dunia, peranan manusia tidak akan sama. Ketiga, manajemen syariah membahas soal sistem. Sistem ini disusun agar perilaku pelaku di dalamnya berjalan dengan baik. Sistem pemerintahan Umar bin Abdul Aziz, misalnya, adalah salah satu yang terbaik. Sistem ini berkaitan dengan perencanaan, organisasi dan kontrol, Islam pun telah mengajarkan jauh sebelum adanya konsep itu lahir, yang dipelajari sebagai manajemen ala Barat ${ }^{1}$.

Menurut Ismail, syari'ah memandang manajemen dari dua sisi, yaitu manajemen sebagai ilmu dan manajemen sebagai aktivitas. Sebagai ilmu, manajemen dipandang sebagai salah satu dari ilmu umum yang lahir berdasarkan fakta empiris yang tidak berkaitan dengan nilai, peradaban (hadharah) manapun. Namun sebagai aktivitas, maka manajemen dipandang sebagai sebuah amal yang akan dimintai pertanggungjawaban di hadapan Allah sehingga ia harus terikat pada aturan syara', nilai dan hadharah Islam. Manajemen Islami (syariah) berpijak pada aqidah Islam. Karena aqidah Islam merupakan dasar Ilmu pengetahuan atau tsaqofah Islam $^{2}$.

Dalam pandangan ajaran Islam, segala sesuatu harus dilakukan secara rapi, benar, tertib, dan teratur. Proses-prosesnya harus diikuti dengan baik. Sesuatu tidak boleh dilakukan secara asal-asalan. Hal ini merupakan prinsip utama dalam ajaran Islam. Arah pekerjaan yang jelas, landasan yang mantap dan cara-cara mendapatkannya yang transparan merupakan amal perbuatan yang dicintai oleh Allah 啮. Sebenarnya Manajemen dalam arti mengatur segala sesuatu agar dilakukan dengan baik, tepat, dan tuntas

* Dosen Tetap Program Studi Pendidikan Agama Islam STAI Al-Hidayah Bogor dan Pemateri Tetap Rubrik Tarbiyatul Awlad di Radio FAJRI 99,3 FM Bogor

1 Didin Hafidhuddin dan Hendri Tanjung, Manajemen Syariah dalam Praktik, Jakarta: Gema Insani, 2008, hlm. 5.

2 M. Karebet Widjajakusuma dan M. Ismail Yusanto, Pengantar Manajemen Syariat, Jakarta: Khoirul Bayan, 2002, hlm.39. 
atau terselesaikan merupakan hal yang disyariatkan dalam ajaran agama Islam ${ }^{3}$.

Demikian pula ketika kita melakukan sesuatu itu dengan benar, baik, terencana dan terorganisasi dengan rapi, maka kita akan terhindar dari keragu-raguan dalam memutuskan atau mengerjakan sesuatu. Kita tidak boleh melakukan sesuatu yang didasarkan oleh keragu-raguan, karena biasanya sesuatu yang dilakukan dengan dasar keraguan akan membuahkan hasil yang tidak optimal dan mungkin akhirnya tidak bermanfaat. Proses-proses manajemen pada dasarnya adalah perencanaan segala sesuatu secara mantap untuk melahirkan keyakinan yang berdampak pada melakukan sesuatu sesuai dengan aturan serta memiliki manfaat. Perbuatan yang tidak ada manfaatnya adalah sama dengan perbuatan yang tidak pernah di rencanakan. Jika perbuatan itu tidak pernah direncanakan, maka tidak termasuk di dalam kategori manajemen yang baik ${ }^{4}$.

Pemikiran manajemen dalam syariah bersumber dari nash-nash al-Qur'an dan petunjuk-petunjuk As-Sunnah. Selain itu pula juga berdasarkan pada nilai-nilai kemanusiaan yang berkembang dalam masyarakat pada waktu tersebut. Berbeda dengan manajemen konvensional, yang merupakan suatu sistem yang aplikasinya bersifat bebas nilai serta hanya berorientasikan pada pencapaian manfaat duniawi semata. Manajemen ini berusaha untuk diwarnai dengan nilai-nilai, namun dalam perjalanannya tidak mampu. Karena tidak bersumber dan berdasarkan petunjuk syariah yang bersifat sempurna, komprehensif dan sarat kebenaran.
Manajemen syariah memiliki beberapa pembahasan penting dalam kaitannya dengan efisiensi dan efektifitas di dalam pelaksanaannya, menurut didin dan Hendri yang dibahas dalam manajemen syariah adalah Perilaku, Struktur organisasi, dan Sistem ${ }^{5}$.

Pembahasan pertama dalam Manajemen Syariah adalah perilaku yang terkait dengan nilai-nilai keimanan dan ketauhidan. Jika setiap perilaku seseorang yang terlibat dalam sebuah kegiatan dilandasi dengan nilai tauhid, maka mereka akan selalu menyadari adanya pengawasan

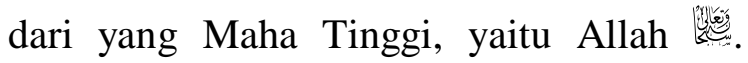
yang akan mencatat setiap amal perbuatan yang baik maupun yang buruk. Hal ini berbeda dengan manajemen konvensional yang sama sekali tidak terkait bahkan terlepas dari nilai-nilai tauhid. Jadi mereka yang menerapkan sistem manajemen ini tidak merasakan adanya pengawasan kecuali semata-mata pengawasan dari pimpinan atau atasan ${ }^{6}$.

Manajemen syariah membahas perilaku yang diupayakan menjadi amal saleh yang bernilai abadi. Istilah amal saleh ini tidak diartikan semata-mata "perbuatan baik" seperti yang dipahami selama ini, akan tetapi amal perbuatan baik yang dilandaskan iman, dengan beberapa persyaratan sebagai berikut ${ }^{7}$ :

a. Niat yang ikhlas karena Allah.

Suatu perbuatan walaupun itu berkesan baik tetapi jika tidak dilandasi keikhlasan karena Allah, maka perbuatan itu tidak dikatakan sebagai amal saleh.
Didin Hafidhuddin dan Hendri Tanjung, Manajemen Syariah dalam Praktik, hlm. 1. Ibid.
5 Ibid., hlm. 5.

6 Didin Hafidhuddin dan Hendri Tanjung, Manajemen Syariah dalam Praktik, hlm. 5. Ibid. hlm. 6. 
b. Tata cara pelaksanaannya sesuai dengan syariat.

c. Dilakukan dengan penuh kesungguhan. Karena perbuatan yang dilakukan dengan asal-asalan bukanlah suatu amal saleh.

Hal kedua yang dibahas dalam manajemen Syariah adalah stuktur organisasi. Stuktur organisasi sangatlah diperlukan oleh setiap manusia, karena dalam mengatur kehidupan dunianya, peranan manusia tidak akan sama. Kepintaran dan jabatan seseorang tidak akan sama. Struktur yang berbeda-beda ini merupakan ujian dari Allah kepada manusia agar mereka bisa mengatur hidupnya menjadi baik. Kelembagaan akan berjalan dengan baik pula apabila dikelola dengan baik ${ }^{8}$.

Hal ketiga yang dibahas dalam manajemen syariah adalah system. Sistem syariah yang disusun harus menjadikan perilaku pelakunya berjalan dengan baik. Sistem manajemen syariah adalah seluruh aturan kehidupan yang bersumber dari alQur'an dan Sunnah rasul' ${ }^{9}$.

Pada tulisan ini pada proses analisisnya, penulis menggunakan pendekatan peran syariah Islam dalam implementasi manajemen pendidikan. Dimana standar yang diambil dalam setiap fungsi manajemen terikat dengan hukumhukum syara' (syariat Islam). Fungsi manajemen sebagaimana kita ketahui ada empat yang utama, yaitu: perencanaan (planning), pengorganisasian (organizing), pengontrolan (controlling), dan pengevaluasian (evaluating).

Peran syariah dalam fungsi manajemen, seperti yang sudah dikemukakan di atas difokuskan pada implementasi manajemen pendidikan di STAI Al-Hidayah Bogor sebagai berikut:

\section{a. Syariah dalam Fungsi Perencanaan di STAI Al-Hidayah Bogor}

Dalam fungsi perencanaan di STAI Al-Hidayah Bogor, penulis mendapati bahwa proses tersebut pada hakikatnya dimulai pada saat mendirikan lembaga STAI Al-Hidayah Bogor, para pendiri yang berlatar belakang aktifis dakwah beserta unsur masyarakat, memiliki rencana, alasan, cita-cita serta maksud yang kuat, yang kemudian dituangkan ke dalam visi, misi, nilai-nilai dan rencana strategi pengembangan lembaga.

Dokumentasi yang memuat pokokpokok pemikiran dasar tersebut kemudian dituangkan dalam bentuk statuta, anggaran dasar dan anggaran rumah tangga lembaga. Kemudian dokumen konsep dasar tersebut dijabarkan ke dalam dokumen rencana strategis (renstra) kemudian dijabarkan lebih rinci ke dalam dokumen rencana operasional (renop) yang memuat sasaran jangka.

Dokumen-dokumen tersebut merupakan rangkaian langkah-langkah STAI AlHidayah Bogor dalam mewujudkan perencanaan atau cita-cita para pendiri ke dalam tataran operasional.

Adapun implementasi syariah dalam fungsi perencanaan di STAI Al-Hidayah Bogor diterapkan dalam ruang lingkup kegiatan sebagai berikut:

1) Perencanaan bidang SDM.

Konsep perencanaan pada bidang SDM diimplementasikan oleh manajemen STAI Al-Hidayah Bogor, melalui tahapan ditetapkannya standar pendidik dan tenaga kependidikan dalam buku pedoman 
penjaminan mutu di STAI Al-Hidayah Bogor ${ }^{10}$.

Standar tersebut meliputi mekanisme standar proses rekrutmen, penetapan standar dosen dan tenaga kependidikan, standar hak dan kewajiban, standar kualifikasi akademik, standar kompetensi, standar jabatan, sertifikasi, beban tugas, rasio dosen terhadap mahasiswa, standar tenaga kependidikan serta evaluasi.

Sistem seleksi atau perekturan sumber daya manusia yang bekerja di STAI Al-Hidayah Bogor disesuaikan dengan mekanisme yang ada dalam Statuta serta dalam pelaksanaanya didampingi oleh pihak Yayasan Islam Al-Huda Bogor dalam penyaringan kelayakan sumber daya manusia yang ada di STAI Al-Hidayah Bogor.

Selain dari itu seleksi yang dilakukan dalam pengembangan sumber daya manusia disesuaikan dengan UndangUndang Republik Indonesia tentang Guru dan Dosen Bab V bagian satu pasal 46 nomor 2 dijelaskan bahwa dosen memiliki akademik minimum:

a) Lulusan program Magister untuk program diploma atau program sarjana;

b) Lulusan program doktor untuk program pasca sarjana.

Contoh penerapan sistem rekrutmen tersebut dapat dilihat pada proses perekrutan tenaga Dosen, yaitu dilakukan melalui rangkaian proses yang dimulai dari calon Dosen mengirimkan surat lamaran kepada Rektor/Ketua dan pihak lembaga menginformasikan secara terbuka melalui media cetak maupun media lain.

10 Pedoman Penjaminan Mutu STAI Al-Hidayah Bogor, 2008, hlm. 57.
Selanjutnya dilakukan penyeleksian calon Dosen sebagai berikut :

a) Seleksi administratif;

b) Seleksi wawancara;

c) Seleksi tertulis dan praktek;

d) Psikotes; dan

e) Menulis karya ilmiyah sesuai dengan bidang keahliannya

Selanjutnya untuk menjadi dosen tetap, seorang dosen harus memiliki kriteria:

a) Sarjana muslim yang memiliki integritas moral yang tinggi;

b) Memiliki IPK minimal 3,00 atau lulusan terbaik pada angkatannya;

c) Menguasai salah satu bahasa asing (bahasa Arab/bahasa Inggris);

d) Lulus tes kemampuan akademik, tes psikologi dan tes kesehatan;

e) Tidak menjadi dosen tetap pada perguruan tinggi lainnya.

Adapun untuk merangsang Dosen tetap dalam kegiatan penelitian dan pengabdian kepada masyarakat, maka STAI Al-Hidayah Bogor memberikan fasilitas sebagai berikut:

a) Setiap Dosen tetap diberikan beban setara 6 SKS untuk kegiatan penelitian dan pengabdian kepada masyarakat;

b) Pihak Program Studi mengupayakan pencarian dana bagi penelitian dan pengabdian kepada masyarakat;

c) Hasil penelitian yang dipublikasikan dalam majalah dan jurnal, atau lainnya diberikan penghargaan, dan

d) Kegiatan penelitian dan pengabdian pada masyarakat merupakan prasyarat mutlak untuk kenaikan kepangkatan Dosen yang bersangkutan.

Proses tersebut di atas dibentuk sebagai sistem penjamin mutu pada bidang 
SDM, yang menjamin SDM yang terekrut kemudian bekerja di STAI Al-Hidayah Bogor merupakan sumber daya muslim yang memenuhi kriteria SDM menurut syariah.

Jika dilihat dari sudut pandang syariah, permasalahan utama bidang SDM adalah penetapan standar perekrutan SDM. Sehingga implementasi syariah pada bidang ini adalah berupa penetapan profesionalisme yang harus dimiliki oleh seluruh komponen SDM suatu lembaga.

Karebet dan Ismail menjelaskan bahwa kriteria profesional menurut syariah adalah harus memenuhi 3 unsur sebagai berikut ${ }^{11}$ :

1) Kafa'ah (ahli di bidangnya)

Islam menetapkan bahwa seorang yang akan diangkat untuk posisi, jabatan atau tugas tertentu, terlebih lagi bila berkaitan dengan kepentingan orang banyak, haruslah orang yang memiliki keahlian dan kecakapan dalam tugas atau

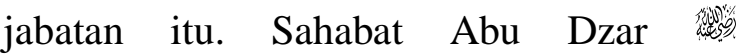
meriwayatkan dari Rasulullah 热玅:

“...Jika suatu urusan (pekerjaan) diserahkan kepada orang yang bukan ahlinya, maka tunggulah kehancurannya". (HR. Bukhari)

Kafa'ah atau keahlian dan kecakapan diperoleh melalui pendidikan, pelatihan dan pengalaman.

2) Himmatul 'amal (etos kerja yang tinggi)

Islam mendorong setiap Muslim untuk selalu bekerja keras, bersungguhsungguh mencurahkan tenaga dan kemampuan dalam menjalankan berbagai

11 M. Karebet Widjajakusuma dan M. Ismail Yusanto, Pengantar Manajemen Syariat, hlm.119. pekerjaan yang menjadi tugas dan tanggungjawabnya.

Dorongan utama seorang Muslim adalah pada sisi bahwa setiap aktivitas seorang Muslim ketika diniatkan Ikhlas dalam rangka mendapatkan ridho Allah maka itu merupakan sebuah ibadah.

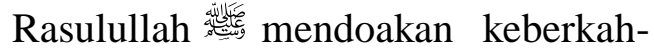
an bagi setiap Muslim yang rajin serta bekerja keras.

"Ya Allah! Berikanlah keberkahan

kepada ummatku, pada usaha yang dilakukannya di pagi hari”. (HR.

Tirmidzi)

Himmatul 'amal atau etos kerja yang tinggi diraih dengan jalan menjadikan motivasi ibadah sebagai pendorong utama di samping motivasi penghargaan (reward) dan hukuman (punishment) serta perolehan material.

3) Amanah (bersungguh-sungguh dan bertanggung jawab)

Sikap amanah mutlak harus ada pada setiap pekerja Muslim, karena Rasulullah memerintahkan kepada setiap Muslim untuk selalu menjaga amanah yang diberikan kepadanya.

"Tunaikanlah amanat terhadap orang yang mengamantimu..."

(HR. Ahmad dan Abu Daud)

"Tidak beriman orang yang tidak memegang amanat..." (HR. Adailami)

Sikap amanah dapat dibangun dengan memperkuat pemahaman Islam dan istiqomah menjalankannya, serta dengan jalan saling menasehati dalam kebajikan dan mencegah berbagai penyimpangan yang terjadi.

Amanah atau sifat terpercaya dan bertanggungjawab juga dapat diperoleh dengan menjadikan tauhid sebagai unsur 
pendorong dan pengontrol utama tingkah laku.

2) Perencanaan Bidang Keuangan

Pengelolaan keuangan STAI AlHidayah Bogor dilaksanakan melalui mekanisme perencanaan anggaran pendapatan dan belanja tahunan, yang ditetapkan pada awal tahun ajaran pada rapat pimpinan dan Yayasan, memuat unsur rencana pendapatan dan rencana belanja selama satu tahun ajaran. Pengelolaan dan pelaporan serta pertanggungjawaban penggunaan dana kepada pemangku kepentingan melalui mekanisme yang transparan dan akuntabel.

Sumber pendanaan diperoleh dari :

a) Yayasan

b) Masyarakat Donatur

c) Mahasiswa

d) Pemerintah

Sumber pendanaan tersebut dialokasikan kepada tiga jenis kegiatan, yaitu: 1) Kegiatan Program Akaemik; 2) Kegiatan Pembinaan Administratif; 3) Kegiatan Pembinaan Kemahasiswaan; dan 4) Pembinaan Kegiatan Khusus.

1) Kegiatan Program Akademik yang berimplikasi terhadap pembiayaan meliputi hal-hal berikut :

a) Biaya Praktikum

b) Biaya Ujian

c) Biaya Pembimbingan

d) Biaya Penelitian dan Pengabdian Pada Masyarakat

e) Biaya Pegembangan Mutu Tenaga Pengajar

f) Biaya Pengembangan Perpustakaan

2) Pembinaan kegiatan Administratif, meliputi;

a) Belanja Pegawai (Dosen Tetap, Dosen Luar Biasa, Pegawai Tetap)

b) Kesejahtraan Pegawai c) Biaya Peningkatan Mutu Tenaga Admistratif

d) Konsumsi Kantor

e) Perjalanan Dinas

f) Biaya Pengadaan Peralatan

g) Barang Habis Pakai

h) Beban Tetap

i) Biaya Pemeliharaan Peralatan

j) Sumbangan Dana Taktis

3) Pembinaan Kegiatan Kemahasiswaan

a) Dana Kegiatan Badan Eksekutif Mahasiswa

b) Dana Kegiatan Himpunan Program Studi (Himajur)

Biaya untuk kegiatan kemahasiswaan tingkat fakultas dianggarkan sesuai dengan rencana kegiatan yang disusun oleh Pembantu Ketua III bidang Kemahasiswaan.

4) Pembinaan kegiatan khusus; Kegiatan Study general dan lainnya.

Sistem alokasi dana dan pengelolaan keuangan di STAI Al-Hidayah menggunakan sistem sentralisasi. Program Studi yang ada menginventarisir serta mengajukan rancangan anggaran kepada Ketua/Rektor kemudian dibantu oleh Pembantu Ketua II (Bidang Keuangan) diajukan ke yayasan untuk disahkan dan kemudian dikelola sendiri.

Mekanisme pertanggung-jawaban STAI Al-Hidayah Bogor sebagai salah satu bentuk pengawasan terhadap seluruh kegiatan yang berimplikasi pada anggaran yang digunakan, juga diterapkan dalam rangka menjaga prosedur dan mekanisme yang sehat dalam penggunaan anggaran. Hal tersebut dilakukan melalui regulasi sebagai berikut :

1) Lembaga Yayasan menunjuk Badan Pengawas Keuangan (BPK) untuk 
mengawasi alur kegiatan keuangan STAI Al-Hidayah Bogor

2) Melakukan verifikasi anggaran dengan mengacu pada:

a) Kebijakan Yayasan Islam Al-Huda Bogor

b) Kebijakan Sekolah Tinggi Agama Islam Al-Hidayah Bogor

c) Usulan Jurusan/Program Studi

d) Pembahasan Anggaran pada tingkat Pimpinan, Jurusan atau Program Studi dengan Sekolah Tinggi

e) Pengesahan rapat senat dengan yayasan

Dalam melakukan menjaga keberlanjutan pengadaan operasional dan prinsip pemanfaatan anggaran, STAI AlHidayah Bogor melakukan mekanisme sebagai berikut :

a) Melakukan efisiensi anggaran

b) Penertiban bidang pelayanan administratif keuangan

c) Bekerjasama dengan badan atau lembaga terkait baik negeri maupun swasta untuk mendapatkan bantuan atau beasiswa; dan

d) Subsidi dari Yayasan.

Sedangkan dari sudut pandang syariah, karebet dan ismail menyatakan, permasalahan utama bidang keuangan adalah penetapan sumber dana dan alokasi pengeluaran. Oleh karena itu implementasi syariah pada bidang ini dapat berupa penetapan syarat kehalalan dana, baik sumber masukan maupun alokasinya. Maka, tidak pernah direncanakan, misalnya, peminjaman dana yang mengandung unsur riba, atau pemanfaatan dana untuk menyogok pejabat ${ }^{12}$.

Dapat disimpulkan bahwa manajemen keuangan syariah adalah sebuah kegiatan manajerial keuangan untuk mencapai tujuan dengan memperhatikan kesesuaiannya pada prinsip-prinsip syariah.

Prinsip syariah pada aspek keuangan merujuk pada banyak ayat-ayat al-Qur'an yang mengajarkan kita bagaimana mengatur keuangan secara Islami diantaranya:

1) Setiap perbuatan akan dimintakan pertanggungjawabannya.

Al-Qur'an surat as-Saba' ayat 37:

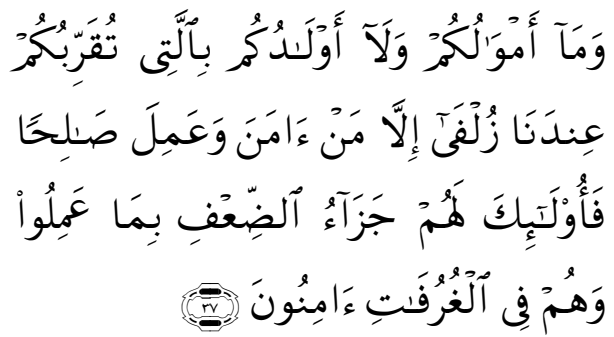

"Dan sekali-kali bukanlah harta dan bukan (pula) anak-anak kamu yang mendekatkan kamu kepada Kami sedikitpun; tetapi orangorang yang beriman dan mengerjakan amal-amal (shaleh, mereka itulah yang memperoleh balasan yang berlipat ganda disebabkan apa yang telah mereka kerjakan; dan mereka aman sentosa di tempat-tempat yang tinggi (dalam syurga)".

2) Setiap harta yang diperoleh terdapat hak orang lain.

Al-Qur'an surat adz-Dzariyaat ayat 19:

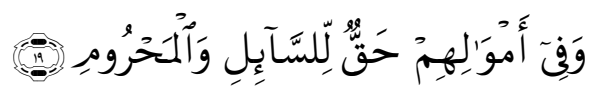

"Dan pada harta-harta mereka ada hak untuk orang miskin yang meminta dan orang miskin yang tidak mendapat bagian"

12 M. Karebet Widjajakusuma dan M. Ismail Yusanto, Pengantar Manajemen Syariat, hlm.119. 
Al-Qur'an surat al-Baqarah ayat 254:

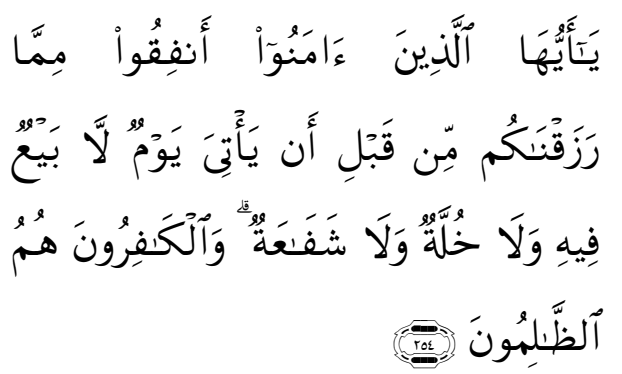

"Hai orang-orang yang beriman, belanjakanlah (di jalan Allah) sebagian dari rizki yang telah Kami berikan kepadamu sebelum datang hari yang pada hari itu tidak ada lagi jual beli dan tidak ada lagi syafa'at. Dan orangorang kafir itulah orang-orang yang zalim".

Al-Qur'an surat al-Baqarah ayat 261:

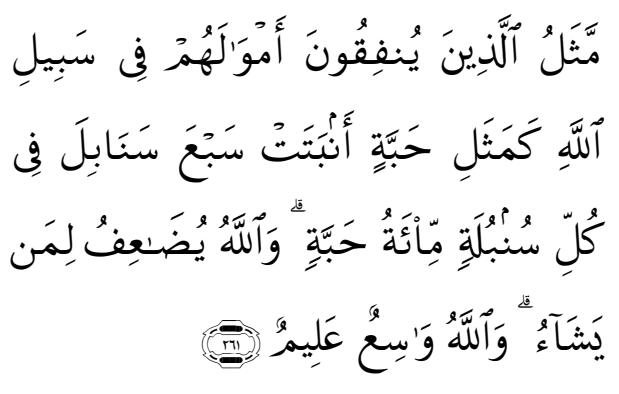

"Perumpamaan (nafkah yang dikeluarkan oleh) orang-orang yang menafkahkan hartanya di jalan Allah adalah serupa dengan sebutir benih yang menumbuhkan tujuh bulir, pada tiap-tiap bulir seratus biji. Allah melipat gandakan (ganjaran) bagi siapa yang Dia kehendaki. Dan Allah Maha Luas (karunia-Nya) lagi Maha Mengetahui".

3) Meninggalkan segala bentuk pemborosan harta

Al-Qur'an surat al-Isra ayat 26-27:
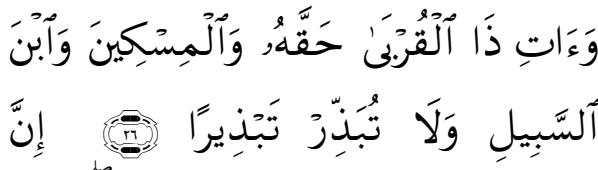

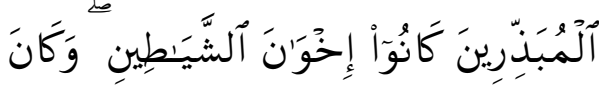

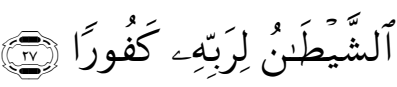

"Dan berikanlah kepada keluargakeluarga yang dekat akan haknya, kepada orang miskin dan orang yang dalam perjalanan dan janganlah kamu menghamburhamburkan (hartamu) secara boros. Sesungguhnya pemborospemboros itu adalah saudarasaudara syaitan dan syaitan itu adalah sangat ingkar kepada Tuhannya".

4) Meninggalkan segala bentuk usaha yang batil dalam mencari penghasilan Al-Qur'an surat an-Nisa ayat 29:

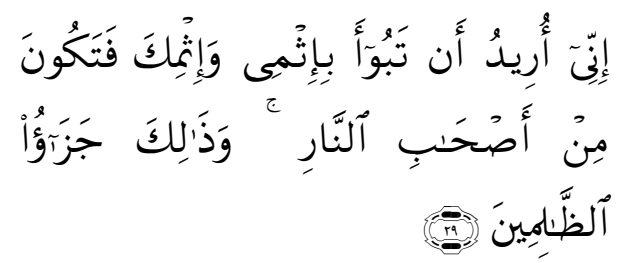

"Hai orang-orang yang beriman, janganlah kamu saling memakan harta sesamamu dengan jalan yang batil, kecuali dengan jalan perniagaan yang berlaku dengan suka sama-suka di antara kamu. dan janganlah kamu membunuh dirimu; Sesungguhnya Allah adalah Maha Penyayang kepadamu”.

5) Meninggalkan segala bentuk usaha yang spekulatif/perjudian.

Al-Qur'an surat al-Maidah ayat 90:

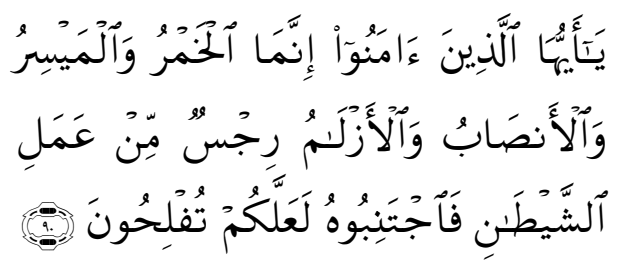

"Hai orang-orang yang beriman, sesungguhnya (meminum) khamar, berjudi, (berkorban untuk) berhala, mengundi nasib dengan panah, adalah termasuk perbuatan syaitan. Maka jauhilah perbuatanperbuatan itu agar kamu mendapat keberuntungan". 
6) Memperbanyak amal/meninggalkan sifat kikir terhadap harta

Al-Qur'an surat al-Isra' ayat 29:

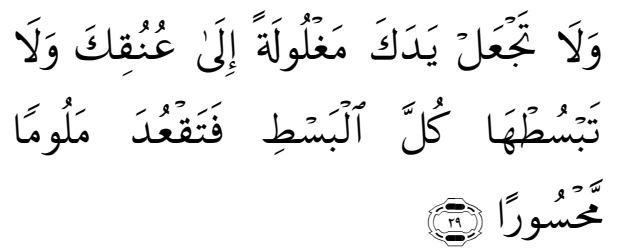

"Dan janganlah kamu jadikan tanganmu terbelenggu pada lehermu dan janganlah kamu terlalu mengulurkannya [kikir] karena itu kamu menjadi tercela dan menyesal.

3) Perencanaan Bidang Pengelolaan STAI Al-Hidayah Bogor menjalankan suatu proses pengelolaan dalam rangka melaksanakan Tridharma perguruan tinggi yang dimulai dari mempersiapkan input yang mencakup mahasiswa, kurikulum, tenaga pendidik dan tenaga kependidikan, fasilitas fisik, informasi dan keuangan. Kemudian input tersebut akan menghasilkan output kegiatan tridharma yaitu berupa alumni atau lulusan dan juga pengabdian kepada masyarakat. Untuk mengelola keseluruhan proses dan berbagai faktor input dan output tersebut, STAI AlHidayah Bogor membentuk suatu manajemen kelembagaan yang baik. Hal tersebut digambarkan pada tabel berikut ini:

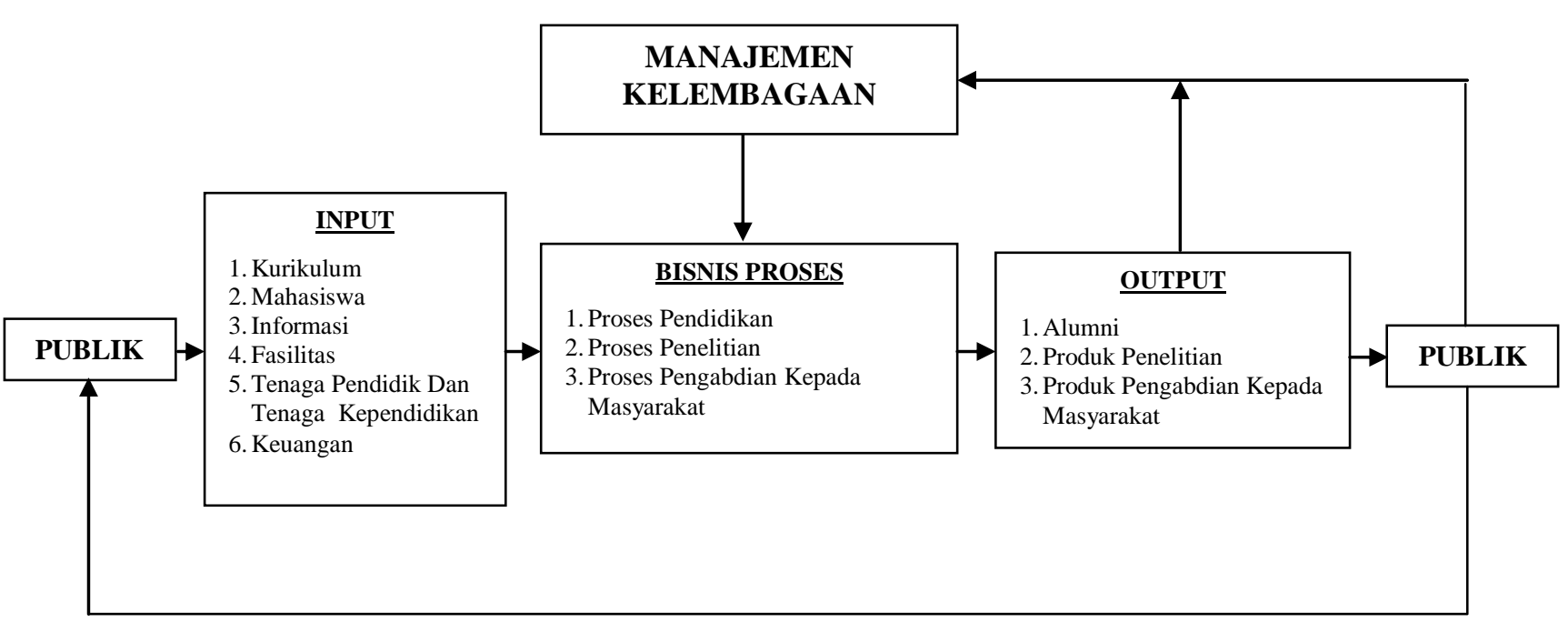

Gambar 1. Proses Utama Pendidikan di STAI Al-Hidayah

Rencana pengelolaan STAI AlHidayah Bogor ditetapkan dalam Pedoman Penjaminan Mutu STAI Al-Hidayah, yang meliputi langkah-langkah sebagai berikut ${ }^{13}$ :

1) Penetapan visi, misi, strategi dan program yang jelas

STAI Al-Hidayah Bogor menetapkan bahwa untuk mencapai manajemen kelembagaan yang baik, pada tahap awal diperlukan kejelasan visi dan misi, sehingga hal tersebut menjadi tujuan dan sasaran pengembangan lembaga pada masa depan. Seorang pemimpin juga diharapkan mampu membangun motivasi kerja dan lingkungan kerja yang dinamis agar pelaksanaan program kerja dapat berjalan dengan suasana kerja yang kondusif.

13 Pedoman Penjaminan Mutu STAI Al-Hidayah Bogor, 2008, hlm. 94. 


\section{2) Kepemimpinan yang efektif}

STAI Al-Hidayah juga beranggapan bahwa peran kepemimpinan sangat penting dalam menerjemahkan visi dan misi tersebut dalam bentuk suatu program kerja yang kongkrit, realistis dan mampu dicapai oleh perangkat kelembagaan yang ada.

3) Pembentukan kelembagaan yang efektif dan efesien

STAI Al-Hidayah Bogor kemudian membentuk struktur kelembagaan berupa lembaga-lembaga atau unitunit dengan tugas pokok dan fungsi yang saling melengkapi dalam rangka mendukung pelaksanaan program yang telah ditetapkan di dalam Statuta, Rencana Kerja (Renstra) maupun Rencana Operasional (Renop). Lembaga atau unit tersebut adalah:

a) Manajemen Akademik;

b) Manajemen Kemahasiswaan;

c) Manajemen Penelitian dan Pengabdian Masyarakat;

d) Manajemen Fasilitas dan Infrastruktur;

e) Manajemen sumber daya manusia;

f) Manajemen keuangan;

g) Manajemen system informasi.

Implementasi syariah pada bidang ini berupa penetapan bahan masukan produksi dan proses yang akan dilangsungkan. Dalam dunia pendidikan, inputnya adalah mahasiswa Muslim dan proses pendidikannya ditetapkan dengan menggunakan kurikulum yang Islami. Dalam Industri pangan, maka masukannya adalah bahan pangan yang telah dipastikan kehalalannya. Sementara proses produksinya ditetapkan berlangsung secara aman dan tidak bertentangan dengan syariah.

\section{4) Perencanaan bidang pemasaran}

Perencanan pemasaran di STAI AlHidayah dilakukan dengan cara mengadakan rapat pimpinan terkait dengan beberapa kegiatan yaitu:

a) Target rekrutmen mahasiswa, yaitu para calon mahasiswa yang berasal dari MA/SMA/SMK dan lulusan Diploma bagi yang ingin melanjutkan studi. Selain itu juga menerima mahasiswa pindahan setelah memenuhi prosedur dan persyaratan yang ditetapkan dalam statuta STAI Al-Hidayah Bogor.

b) Sistem rekrutmen calon mahasiswa digolongkan menjadi dua bagian, yaitu sistem rekrutmen terpusat yang artinya pelaksanaan rekrutmen calon mahasiswa dilakukan oleh suatu panitia pada tingkat STAI Al-Hidayah Bogor yang dibentuk berdasarkan SK Ketua STAI Al-Hidayah Bogor dan dilaksanakan oleh panitia penerimaan mahasiswa baru (PPMB). Sedangkan rekrutmen jurusan atau program studi dilakukan oleh jurusan atau program studi dengan SK pengangkatan panitia dari Kepala Jurusan atau program studi. Perbedaannya terletak pada segi lingkup kerja dan karakteristik calon mahasiswa masing-masing jurusan atau program studi yang berbeda.

c) Strategi rekrutmen STAI AlHidayah Bogor dilakukan melalui kegiatan publikasi di berbagai media promosi (spanduk, brosur, surat kabar dan radio Fajar Imani 99.3 FM Bogor, majalah). Informasi melalui mahasiswa dan pegawai, kunjungan ke berbagai 
lembaga pendidikan, serta melalui panggilan kepada calon yang potensial dan kegiatan mahasiswaan.

d) Melakukan kunjungan formal dan informal ke sekolah, madrasah dan pondok pesantren.

e) Melakukan pemberian beasiswa bagi siswa yang berprestasi.

f) Melakukan dialog interaktif rutin/launching program-program STAI Al-Hidayah di radio Fajri 99.3 Fm Bogor.

g) Melakukan sosialisasi di berbagai media informasi.

h) Melakukan pendekatan dengan menggunakan metode bola salju, yaitu dengan informasi dari dosen, pegawai, mahasiswa, alumni kepada masyarakat umum.

Implementasi syariah pada bidang ini dapat berupa penetapan segmentasi pasar, targeting dan positioning, juga termasuk promosi. Dalam dunia pendidikan, misalnya, segmen yang dibidik adalah SDM Muslim berupa mahasiswa. Target yang ingin dicapai adalah output didik (SDM) yang profesional. Dalam promosi tidak melakukan kebohongan, penipuan ataupun penggunaan wanita tanpa menutup aurat sempurna.

\section{5) Syariah dalam Fungsi Peng- organisasian di STAI Al-Hidayah Bogor}

Fungsi pengorganisasian di STAI AlHidayah Bogor dilaksanakan melalui sistem tata pamong yang didokumentasikan dengan tata aturan organisasi yang melipui; tata cara pemilihan pimpinan, etika dosen, etika mahasiswa, etika tenaga kependidikan, sistem penghargaan dan sanksi serta pedoman dan prosedur pelayanan (administrasi, perpustakaan, laboratorium) ${ }^{14}$.

Struktur organisasi yang ada di STAI Al-Hidayah Bogor meliputi Ketua Sekolah Tinggi, Pembantu Ketua-I yang menangani Bidang Akademik, Pembantu Ketua-II yang menangani Bidang Keuangan dan Kepegawaian dan Pembantu Ketua-III menangani Bidang Kemahasiswaan. Kemudian dalam penyelenggaraan Tridharma Perguruan Tinggi dan teknis di lapangan masing-masing dipimpin oleh Ketua Jurusan. Saat ini terdapat empat jurusan antara lain; Ketua Jurusan Tarbiyah, Ketua Jurusan Syariah, Ketua Jurusan dan Ketua Jurusan Ekonomi Islam. Masing-masing dibantu oleh Sekretaris Jurusan, ditambah unsur pelaksana Akademik yaitu Ketua Program Studi dibantu Sekretaris Program Studi, Kepala Tata Usaha yang dibantu Kepala Sub Bagian Akademik, Administrasi dan Keuangan, Rumah Tangga, Personalia dan Tenaga Pustakawan untuk menunjang proses belajar mengajar serta pelayanan administrasi atau akademik bagi dosen maupun mahasiswa. Disamping itu ada Kepala Laboratorium, Kepala Perpustakaan serta Gugus Kendali Mutu (GKM) dan Unit Pelaksana Teknis (UPT). Hirarki seperti ini mampu mengefektifkan dan mengefesiensikan program kerja program studi.

Sedangkan beberapa implementasi syariah dalam fungsi pengorganisasian dijelaskan oleh Ismail terdapat pada beberapa aspek seperti digambarkan sebagai berikut ${ }^{15}$ :

14 Borang Akreditasi Program S-1 STAI AlHidayah Bogor, 2008, hlm. 6.

15 M. Karebet Widjajakusuma dan M. Ismail Yusanto, Pengantar Manajemen Syariat, hlm. 145 . 


\begin{tabular}{|c|c|}
\hline STRUKTUR & $\begin{array}{l}\text { AQAD } \\
\text { KAFAAH } \\
\text { AMANAH }\end{array}$ \\
\hline $\begin{array}{l}\text { TUGAS DAN } \\
\text { WEWENANG }\end{array}$ & $\begin{array}{l}\text { SESUAI AQAD } \\
\text { KESANGGUPAN } \\
\text { KEMAMPUAN }\end{array}$ \\
\hline $\begin{array}{l}\text { HUBUNGAN } \\
\text { KARYAWAN }\end{array}$ & $\begin{array}{l}\text { MUAMALAH } \\
\text { AMAR MA'RUF } \\
\text { NAHI MUNKAR }\end{array}$ \\
\hline
\end{tabular}

Gambar 2. Contoh Penerapan Syariah dalam Fungsi Pengorganisasian

\section{a) Aspek Struktur}

Pada aspek ini syariah di implementasikan pada SDM yaitu hal-hal yang berkorelasi dengan faktor Profesionalisme serta aqad pekerjaan. Harus dihindarkan penempatan SDM pada struktur yang tidak sesuai dengan kafa'ahnya atau dengan aqad pekerjaannya. Yang pertama akan menyebabkan timbulnya kerusakan, dan yang kedua bertentangan dengan keharusan dan kesesuaian antara aqad dan pekerjaan.

b) Aspek Tugas dan Wewenang

Implementasi syariah dalam hal ini terutama di tekankan pada kejelasan tugas dan wewenang masing-masing bidang yang diterima oleh para SDM pelaksana berdasarkan kesanggupan dan kemampuan masing-masing sesuai dengan aqad pekerjaan tersebut.

c) Aspek Hubungan Karyawan

Implementasi syariah pada aspek ini berupa penetapan budaya organisasi bahwa setiap interaksi antar SDM adalah hubungan muamalah yang selalu mengacu pada amar ma'ruf dan nahi munkar.

\section{6) Peran Syariah dalam Fungsi Pengontrolan di STAI Al-Hidayah Bogor.}

Berikut ini adalah beberapa Implementasi syariah dalam fungsi pengarahan adalah merupakan tugas utama dari fungsi kepemimpinan.

Fungsi kepemimpinan selain sebagai penggembala (pembimbing, pengarah, pemberi solusi dan fasilitator), maka implementasi syariah dalam fungsi pengarahan dapat dilaksankan pada dua fungsi utama dari kepemimpinan itu sendiri, yakni fungsi pemecahan masalah (pemberi solusi) dan fungsi sosial (fasilitator). Pertama, fungsi pemecahan masalah. Mencakup pemberian pendapat, informasi dan solusi dari suatu permasalahan yang tentu saja selalu disandarkan pada syariah, yakni dengan di dukung oleh adanya dalil, argumentasi atau hujah yang kuat. Fungsi ini diarahkan juga untuk dapat memberikan motivasi ruhiyah kepada para SDM organisasi.

a) Motivasi

Seorang pemimpin bertugas untuk memotivasi, mendorong dan memberi keyakinan kepada orang yang dipimpinnya dalalm suatu entitas atau kelompok, baik itu individu sebagai entitas terkecil sebuah komunitas ataupun hingga skala negara, untuk mencapai tujuan sesuai dengan kapasitas kemampuan yang dimiliki. Pemimpin harus dapat memfasilitasi anggotanya dalam mencapai tujuannya. Maka dalam hal motivasi ini seorang pemimpin harus dapat memberikan kekuatan ruhiyah. Kekuatan yang muncul karena adanya kesadaran akibat pemahaman (mafhum) akan maksud dan tujuan yang mendasari amal perbuatan yang dilakukan. Oleh karena itu wajib bagi pemimpin untuk memberikan pemahaman dan motivasi kepada setiap orang yang dipimpinnya, agar perbuatan mereka dapat dilaksanakn dengan baik dan sempurna, tidak keluar dari tanggung jawab dan wewenangnya. 
b) Fasilitator

Kedua, fungsi sosial. Fungsi sosial yang berhubungan dengan interaksi antar anggota komunitas dalam menjaga suasana kebersamaan tim agar tetap sebagai team (together everyone achieve more). Setiap anggotanya harus dapat bersinergi dalam kesamaan visi, misi dan tujuan organisasi. Suasana tersebut dapat diringkas dalam formula three in one (3 in 1), yakni kebersamaan seluruh anggota dalam kesatuan bingkai thinking-afkar (ide atau pemikiran), feeling-masyair (perasaan) dan rule of game-nidzam (aturan bermain). Tentu saja interaksi yang terjadi berada dalam koridor amar ma'ruf dan nahi munkar.

\section{7) Peran Syariah dalam Evaluasi}

Fungsi manajerial pengawasan adalah untuk mengukur dan mengoreksi prestasi kerja bawahan guna memastikan bahwa tujuan organisasi disemua tingkat dan rencana yang di desain untuk mencapainya, sedang dilaksanakan. Pengawasan membutuhkan prasyarat adanya perencanaan yang jelas dan matang serta struktur organisasi yang tepat. Dalam konteks ini, implementasi syariah diwujudkan melalui tiga pilar pengawasan, yaitu:

a) Ketaqwaan individu. Seluruh personel SDM perusahaan dipastikan dan dibina agar menjadi SDM yang bertaqwa.

b) Kontrol anggota. Dengan suasana organisasi yang mencerminkan formula TEAM, maka proses keberlangsungan organisasi selalu mendapatkan pengawalan dari para SDM-nya agar sesuai dengan arah yang telah ditetapkan.

c) Penerapan (supremasi) aturan. Organisasi ditegakkan dengan aturan main yang jelas dan transparan serta- tentu saja-tidak bertentangan dengan syariah.

\section{8) Peran Syariah dalam pengelolaan SDM}

a) Motivasi Bekerja

Al-Qur'an memberikan motivasi untuk bekerja keras dan menjanjikan pertolongan Alloh dan petunjuk-Nya bagi mereka yang berjuang dan berlaku baik. Alloh Ta'ala berfirman al-Qur'an surat Al Ankabut [29] ayat 6:

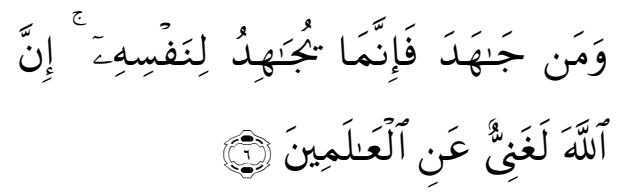

"Dan barangsiapa yang berjihad, Maka Sesungguhnya jihadnya itu adalah untuk dirinya sendiri. Sesungguhnya Allah benar-benar Maha Kaya (tidak memerlukan sesuatu) dari semesta alam".

b) Ditetapkannya Kriteria Pekerja Muslim

(1) Pegawai Yang Menunaikan Pekerjaannya Dengan Ikhlas Mendapat Balasan Dunia dan Akhirat.

Apabila seorang pegawai yang menunaikan pekerjaannya dengan sungguhsungguh mengharapkan pahala dari Allah, maka ia telah menunaikan kewajibanya dan berhak mendapatkan balasan atas pekerjaanya di dunia dan beruntung dengan pahala di kampung akhirat. Nash-nash syariyah menunjukkan bahwasanya upah dan pahala atas apa yang dikerjakan oleh seorang dari pekerjaan diperoleh dengan ikhlas dan mengharapkan wajah Allah. Allah Ta'ala berfirman dalam al-Qur'an surat an-Nisa' ayat 114:

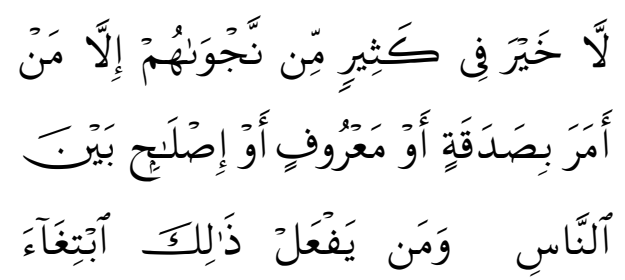




\section{مَرضَاتِ اللَّهِ فَسَوْفَ نُؤتِيهِهِ أَجْرًا عَظِيهًا}

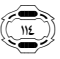

"Tidak ada kebaikan pada kebanyakan bisikan-bisikan mereka, kecuali bisikan-bisikan dari orang yang menyuruh (manusia) memberi sedekah, atau berbuat ma'ruf, atau mengadakan perdamaian di antara manusia. Dan barangsiapa yang berbuat demikian karena mencari keridhaan Allah, maka kelak Kami memberi kepadanya pahala yang besar".

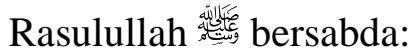

"Dan tidaklah engkau menafkahkan satu nafkah karena mengharapkan wajah Allah melainkan engkau mendapatkan pahala dengannya hingga sesuap yang engkau suapkan di mulut istrimu". (Diriwayatkan AlBukhari dan Muslim)

(2) Amanah dan Kuat

Landasan dalam memilih seorang pegawai atau pekerja hendaklah ia seorang yang kuat lagi amanah. Karena dengan kekuatan ia sanggup melaksanakan pekerjaan yang diembankan kepadanya, dan dengan amanah ia menunaikan sesuai dengan tugas dan tanggung jawabnya. Dengan amanah ia akan meletakkan perkara-perkara pada tempatnya, sedangkan dengan kekuatan ia sanggup menunaikan kewajibannya.

Allah Ta'ala berfirman dalam alQur'an surat al-Qoshsosh ayat 26:

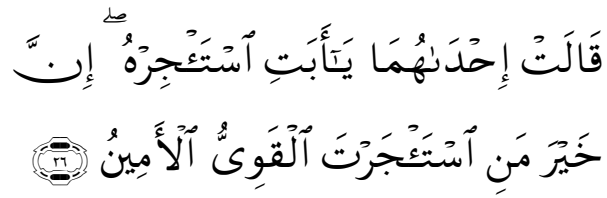

"Salah seorang dari kedua wanita itu berkata: "Ya bapakku ambillah ia sebagai orang yang bekerja (pada kita), karena sesungguhnya orang yang paling baik yang kamu ambil untuk bekerja (pada kita) ialah orang yang kuat lagi dapat dipercaya"

(3) Menjaga Jam Kerja Untuk Kepentingan Pekerjaan

Wajib atas setiap pegawai dan pekerja untuk menggunakan waktu yang telah dikhususkan untuknya,dan sebagaimana seseorang ingin mengambil upahnya dengan sempurna serta tidak ingin dikurangi bagianya sedikitpun, maka hendaklah ia tidak mengurangi sedikit pun dari jam kerjanya untuk sesuatu yang bukan kepentingan kerja. Allah telah mencela al Muthaffifin (orang-orang yang curang) dalam timbangan, yang menuntut hak mereka dengan sempurna dan mengurangi hak-hak orang lain. Allah Ta'ala berfirman dalam al-Qur'an surat al-Muthaffifin ayat 1-6:

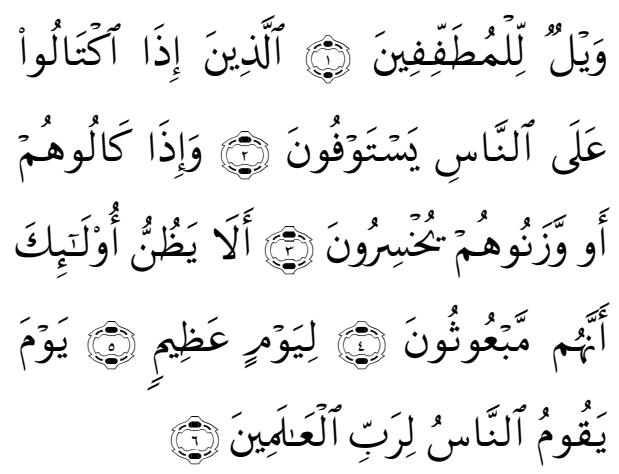

"Kecelakaan besarlah bagi orangorang yang curang,(yaitu) orangorang yang apabila menerima takaran,dari orang lain mereka minta dipenuhi, dan apabila mereka menakar atau menimbang untuk orang lain, mereka mengurangi, tidaklah orang-orang itu menyangka, bahwa sesungguhnya mereka akan dibangkitkan, pada suatu hari yang besar, (yaitu) hari (ketika) manusia berdiri menghadap Tuhan semesta alam". 
(4) Atasan Adalah Teladan Bagi Bawahannya Dalam BersungguhSungguh Melaksanakan Tugasnya Apabila para atasan pegawai melaksanakan kewajiban-kewajiban mereka dengan sempurna, Pegawai pegawai yang menjadi bawahanya akan akan mencontoh mereka. Dan setiap pimpinan dalam suatu pekerjaan akan di minta pertanggung jawabanya terhadap dirinya dan orang-orang yang dipimpinnya.

Rasulullah shallallahu alaihi wa sallam bersabda:

"Setiap kalian adalah pemimpin dan akan diminta pertanggungjawabanya tentang apa yang dipimpinnya. Seorang amir yang memimpin manusia, ia memimpin mereka dan akan diminta pertanggungjawabanya tentang mereka, seorang laki-laki memimpin atas keluarganya dan dia akan diminta pertanggungjawabannya tentang mereka, dan seorang wanita adalah pemimpin atas rumah suami dan anaknya,dia akan diminta pertanggung jawabanya tentang mereka dan seorang budak pemimpin atas harta tuanya dan dia akan di minta pertnggungjawabanya terhadapnya, ketahuilah setiap kalian adalah pemimpin dan setiap kalian akan diminta pertanggungjawaban terhadap apa yang dipimpinya". (Diriwayatkan al-Bukhari, no. 2554, bab karahiat at tathawul 'al ar raqiq dan Muslim, no. 4828, bab fadilah al- imam al 'adil wa 'uqubatul ja'ir).

(5) Perlakuan Pegawai Kepada Orang Lain Seperti Apa Ia Ingin Diperlakukan

Nasihat memiliki kedudukan yang agung di dalam Islam, oleh karenanya Rasulullah shallallahu alaihi wa sallam bersabda:
"Agama adalah nasihat", kami berkata, "Untuk siapa?"Beliau bersabda, "Untuk Allah, KitabNya dan para pemimpin kaumMuslimin serta sesama mereka". (Diriwayatkan oleh Muslim dari AbiTamrin bin Aus Ad-Dari radhiyallahu 'anhu, haditsno. 205, bab. Bayan anna ad din an nashihah).

(6) Pegawai Mendahulukan Yang Dahulu Dalam Berurusan

Termasuk sikap yang adil dan inshaf hendaknya seorang pegawai tidak mengakhirkan orang yang duluan dari orang-orang yang berurusan, atau mendahulukan orang yang belakangan. Akan tetapi ia mendahulukan berdasarkan urutan yang terdahulu. Dalam hal yang seperti ini memudahkan pegawai dan orang-orang yang berurusan.

Dari Abu Hurairah radhiyallahu 'anhu, ia berkata, "Ketika Nabi di suatu majelis berbicara kepada orang-orang, datanglah seorang Arab badui lantas berkata, "Kapan terjadinya Kiamat? Rasulullah terus berbicara, sebagian berkata, "Beliau mendengar apa yang dikatakanya dan beliau membencinya". Sebagian lagi mengatakan, "Bahkan ia tidak mendengar", sehingga tatkala beliau menyelesaikan pembicara-annya beliau berkata, "Mana orang yang bertanya tentang hari Kiamat?" Ia berkata, "Ini aku wahai Rasulullah". Rasul bersabda, "Apabila Amanah telah disiasiakan maka tunggulah hari Kiamat". Ia bertanya lagi, "Bagaimana menyia-nyiakanya?" Beliau menjawab, "Apabila di serahkan urusan kepada yang bukan ahlinya maka tunggulah hari kiamat”. (HR. Bukhari) 
(7) Pegawai Harus Memiliki Sifat 'Iffah (Menjaga Kehormatan) Dan Bersih dari Menerima Sogokan dan Hadiah

Setiap pegawai wajib menjadi seorang yang menjaga kehormatan dirinya, berjiwa mulia dan kaya hati. Jauh dari memakan harta-harta manusia dengan batil, dari apa-apa yang diberikan kepadanya berupa suap walau dinamakan dengan hadiah. Karena apabila dia mengambil harta manusia dengan tanpa hak berarti ia memakannya dengan batil merupakan salah satu sebab tidak dikabulkanya do'a.

Abu Sa'id Hamid as Saidi berkata:

"Rasulullah mempekerjakan seseorang dari suku Asad namanya Ibnu Lathbiyah untuk mengumpulkan zakat. Maka tatkala ia telah kembali, ia berkata; "ini untuk engkau dan ini untukku dihadiahkan untukku. Ia (Abu Hamid) berkata; "Maka Rasulullah berdiri di atas mimbar, memuji dan meтuja Alloh dan bersabda; "Kenapa petugas yang aku utus lalu ia mengatakan; ini untuk kalian dan ini dihadiahkan untukku? Kenapa ia tidak duduk di rumah bapaknya atau ibunya sehingga dia melihat apakah dihadiahkan kepadanya atau tidak?!”. (HR. Bukhari)

\section{Penutup}

Berkenaan dengan manajemen pendidikan, Islam telah menggariskan bahwa hakikat amal perbuatan haruslah berorientasi bagi pencapaian ridla Allah SWT. Bila perbuatan manusia memenuhi dua syarat itu sekaligus, maka amal itu tergolong ahsan (ahsanul amal), yakni amal

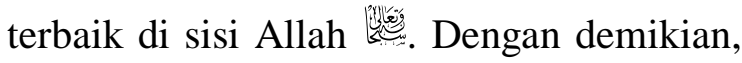
keberadaan manajemen organisasi dipandang pula sebagai suatu sarana untuk memudahkan implementasi Islam dalam kegiatan organisasi tersebut. Implementasi nilai-nilai Islam berwujud pada difungsikannya Islam sebagai kaidah berpikir dan kaidah amal dalam seluruh kegiatan organisasi. Nilai-nilai Islam inilah sesungguhnya nilai utama organisasi yang menjadi payung strategis hingga taktis seluruh aktivitas organisasi.

Sebagai kaidah berpikir, aqidah dan syariah difungsikan sebagai asas atau landasan pola pikir dalam beraktivitas. Sedangkan sebagai kaidah amal, syariah difungsikan sebagai tolok ukur kegiatan. Tolok ukur syariah digunakan untuk membedakan aktivitas yang halal atau haram. Hanya kegiatan yang halal saja yang dilakukan oleh seorang muslim, sementara yang haram akan ditinggalkan semata-mata untuk menggapai keridloan

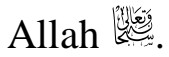

\section{Daftar Pustaka}

al Jamali, Muhammad Fadhil, 1986, Falsafah Pendidikan dalam alQur'an, Surabaya: Bina Ilmu.

al Shabuni,Muhammad Ali,Shafwat al Tafasir, Jilid IV, Beirut: Dar al Fikr

al Syaibani, Omar Muhammad al Toumi, 1999, Falsafah Pendidikan Islam, (Terj.) Hasan Langgulung, Jakarta: Bulan Bintang.

al-Abrasyi, Muhammad Athiyah, 1993, Dasar-dasar Pokok Pendidikan Islam, Jakarta:Bulan Bintang.

al-Attas, Muhammad al-Naquib, 1998, Konsep Pendidikan dalam Islam, Bandung: Mizan.

Hafidhuddin, Didin dan Hendri Tanjung, 2003, Manajemen Syariah dalam Praktik, Jakarta: GIP.

1999, Manajemen Edisi 2,

Yogyakarta: BPFE-Yogyakarta.

Hasan, M. Ali, 2004, Berbagai Macam

Transaksi dalam Islam (Fiqh Muamalat), Jakarta: PT. Raja 
Grafindo Persada.

Hasibuan, 1994, Manajemen Sumber Daya

Manusia, Jakarta: Haji Masagung.

Ibrahim, Mahdi bin, 1997, Amanah dalam Manajemen, Jakarta: Pustaka Al Kautsar.

Jabal, Nizar Saad, 2008, Konsep Manajemen SDM, Makalah Training Manajemen Pendidikan Islam, Jakarta: Yayasan Al Sofwa.

Khakim, Abdul, 2006, Aspek Hukum Pengupahan Berdasarkan UU Nomor 13 Tahun 2003, Bandung: PT. Citra Aditya Bakti.

Khusnuridlo, 2000, Manajemen Lembaga Pendidikan Islam, Jember: STAIN Jember.

Kurmen, 2002, Kepemimpinan Lembaga Pendidikan, (Makalah), Jember: STAIN Jember.

Mahmud Yunus, tt., Kamus ArabIndonesia, Jakarta: PT. Hidakarya Agung.

Makalah Training Manajemen Pendidikan Islam, 2007, Jakarta: Yayasan Al Sofwa.

Manullang , M., 1989, Dasar-Dasar Manajemen, Jakarta: Ghalia Indonesia.

Marimba, Ahmad , D., 1980, Filsafat Pendidikan Islam, Bandung: PT. AlMaarif, 1980.

Marno, 2007, Islam By Management and Leadership, Jakarta: Lintang Pustaka.

Mulyasa, E., 2003, Manajemen Berbasis Sekolah: Konsep, Strategi dan Implementasi, Bandung: PT. Remaja Rosdakarya.

, 2004, Kurikulum Berbasis Kompetensi: Konsep, Strategi dan Implementasi, Bandung: PT. Remaja Rosdakarya.
Nasution, S.,1991, Pengembangan Kurikulum Pendidikan, Bandung: Cipta Adirya Bakti.

Nata, Abuddin, 2010, Manajemen Pendidikan, Jakarta: Kencana. , 2010, Ilmu Pendidikan Islam, Jakarta: Prenada Media.

Ojon, Analisis sistem pengupahan pada perusahaan berbasis syariah (studi kasus cv. al manar herbafit), 2011, Yogyakarta: STEI Hamfara.

Perpustakaan Islam Digital, Jakarta: Pusat Kajian Hadis.

Poerwadarminta, W.J.S., 2007, Kamus Umum Bahasa Indonesia, Jakarta: Balai Pustaka.

Qomar,Mujammil,2007, Manajemen Pendidikan Islam: Strategi Baru Pengelolaan Lembaga Pendidikan Islam, Jakarta: Erlangga.

Ramayulis, 2010,Ilmu Pendidikan Islam, Jakarta: Kalam Mulia.

Ruky, Ahmad S., 2006, Manajemen Penggajian dan Pengupahan untuk Karyawan Perusahaan, Jakarta:PT. Gramedia Pustaka Utama.

Sekolah Tinggi Agama Islam Al-Hidayah, 2012, Buku Pedoman Panduan Akademik, Cetakan I, Bogor: STAIA.

, 2008, Buku Pedoman Penjaminan Mutu, Bogor: STAIA.

, 2008, Sistem Penggajian Islami, Jakarta: Raih Asa Sukses. , 2010, BukuBorang Akreditasi

Program Studi S-1, Bogor: STAIA. , 2008, Sistem Penggajian Islami, Jakarta: Raih Asa Sukses.

Siagian, Sondang, 1992, Fungsi-Fungsi Manajerial, Jakarta:Bumi Aksara.

Sulistyorini, 2009, Manajemen Pendidikan Islam; Konsep, Strategi dan Aplikasi, Yogyakarta: Teras.

Tafsir, Ahmad, 2008, Ilmu Pendidikan 
dalam Perspektif Islam,

Bandung:Remaja Rosdakarya.

Taufik, Ali Muhammad, 2004, Praktik

Manajemen Berbasis Al-Qur'an,

Jakarta: Gema Insani.

Terry R, George, 2001, Dasar-Dasar

Manajemen, Jakarta: Bumi Aksara.

Tim Penulis Komunitas Pengusaha Rindu

Syariah (PRS), Pokok-Pokok

Panduan Implementasi Syariah dalam Bisnis

Yunus, Mahmud, 1990, Kamus ArabIndonesia, Jakarta: PT.Mahmud Yunus Wadzuryah.

Yusanto et. al., Muhammad Ismail, 2002, Pengantar Manajemen Syariat, Jakarta: Khairul Bayan.

http://staia.wordpress.com 